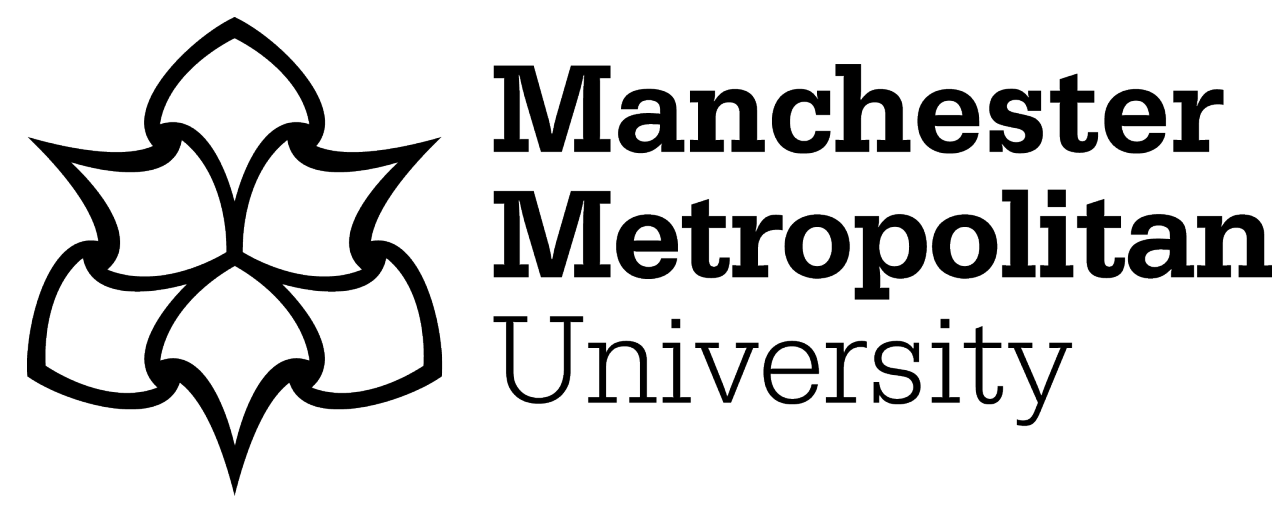

Crowley, JP (2017) Patriotism in Ancient Greece. In: The Handbook of Patriotism. Springer. ISBN 978-3-319-30534-9

Downloaded from: https://e-space.mmu.ac.uk/619426/

Version: Accepted Version

Publisher: Springer

DOI: https://doi.org/10.1007/978-3-319-30534-9_7-1

Please cite the published version 


\section{Patriotism in Ancient Greece}

\section{Introduction}

Patriotism is a word derived from ancient Greek, and to judge from modern definitions of the concept, which emphasise a person's willingness to fight, kill and die for his or her political community, it was something the Greeks knew all too well. Their history is dominated by war, but if this bellicosity demonstrates the fervency of Greek patriotism, it also reveals that it was far from monolithic. Instead, as the Greeks themselves recognised, two types of patriotism co-existed in classical Greece, namely 'higher patriotism', which focused on the common identity of the Greeks as a distinct culture group, and 'lower patriotism', which focused on the narrower political community or polis. This patriotic duality naturally created the potential for both cooperation and conflict, and as this chapter will reveal, it exercised a profound influence on both the Greeks and their history.

\section{Higher Patriotism}

The Greeks believed that they shared a collective Hellenic identity which was defined, in the late fifth century $\mathrm{BC}$, by the historian Herodotus (The Histories, 8.144.2) on the basis of four criteria. The first was shared blood, which all Greeks supposedly inherited from their eponymous ancestor, Hellen, from whom they also took their collective name: the Hellenes (Hesiod, fr.9 M-W; Thucydides, The History of the Peloponnesian War, 1.3.2). The second was shared language, which was emphasised by the Greeks (cf. Sophocles, Philoctetes 220-35) primarily because it was linked, in their imagination, with the capacity for logical thought, as well as their superiority to barbarians. They, by definition, did not speak Greek, and as such, they were both linguistically and intellectually inferior (Cartledge, 2002a; Hall 1989, 1993; Mitchell 2007). The third was a shared set of religious beliefs which, despite the lack of dogma and the fluidity inherent to polytheism, were felt by the Greeks to 
be both distinct and distinctly Greek (Price 1999; Burkert 1985). The fourth was shared culture, through which the Greeks expressed a common identity, particularly in their manner of dress (they wore tunics, not trousers; cf. Evans \& Abrahams 1964), their cuisine (they consumed wine and olive oil not beer and butter; cf. Wilkins \& Hill 2006), their political systems (they were citizens not subjects; cf. Mitchell 2007) and their style of warfare (they fought with the spear not with the bow; cf. Hanson 2009).

The Greeks then, clearly felt themselves to be a distinct and delimited group, and as their history reveals, their loyalty to this group was strong enough to form the basis for collective action against an outside power, such as Persia (cf. esp. Herodotus, The Histories, 1.1.0). However, while the Greeks formed one people, they lived in many different political communities, and their 'higher patriotism' was undercut by more local loyalties which focused firmly on the polis.

\section{Lower Patriotism}

This quintessentially Greek socio-political system was found both in Greece proper and in the areas the Greeks colonised (for an inventory of which, see Hansen \& Nielsen 2004). The term polis (pl. poleis) is often translated as city-state, but as Aristotle (Politics 1.1252b, 3.1276b; cf. Thucydides, History of the Peloponnesian War 1.10.2) reveals, the polis was neither a city nor a geographical location, it was, instead, a political community. This community was comprised solely of adult male citizens who exercised their political prerogatives within a wider and politically excluded population of women, children, slaves and resident foreigners (for further discussion, see Finley 1983).

Of course, the precise nature of these communities varied but, as Murray (2012; cf. Runciman 1990) demonstrates, they had five things in common. Firstly, they were small. Athens, whose citizens numbered in their tens of thousands (Thucydides, History of the Peloponnesian War 2.13.6-7), was atypical: most Greek poleis were considerably smaller, 
and some had only a few hundred citizens (Hansen and Nielsen 2004). Secondly, they were politically autonomous, that is to say they were sovereign and self-governing (Finley 1983). Thirdly, they were socially homogeneous, in that citizens, despite differences in personal wealth and pedigree, shared the same rights and obligations, as well as the same core norms and values (Crowley 2012; Todd 1990). Fourthly, they were legally regulated, that is to say relations between individuals, both citizens and non-citizens, were governed not by force but by an accepted legal apparatus (Todd 1993). Fifthly, they were cohesive, in that citizenship, for those who enjoyed it, was not an abstract condition but the concrete right to belong, for better or worse, to the wider collective of citizens (cf. Thucydides, History of the Peloponnesian War 2.60.3-4, 62.3-5).

Unsurprisingly, such communities easily attracted the loyalties of their citizens, whose patriotism was further reinforced by the unique geo-political environment those insular, antagonistic and competitive communities collectively created. This was characterised by a high level of interstate competition, which was both conducted under the assumption that war was an acceptable way to settle disputes and unconstrained by an effective system of 'international' law (Plato, Laws 1.625e-626a; Thucydides, History of the Peloponnesian War 5.89.1; Xenophon, Memorabilia 2.1.28; Crowley 2012). This is not, of course, to suggest that the Greeks lived in some kind of Hobbesian state of nature: they understood the concept of 'international' law and acted according to a broad legal framework (Thucydides, History of the Peloponnesian War 4.97.2; Low 2007; Sheets 1994) advanced enough to offer interstate arbitration as an alternative to armed conflict (see, for instance Thucydides, History of the Peloponnesian War 5.75.1; cf. 1.120.3, 2.61.1). Legal sophistication, then, was not lacking: what was, however, was an effective means of enforcement. 
This, naturally, was left to the gods, not just because they were the only overarching authority recognised by the Greeks, but also because, in the profoundly pious environment of classical Greece, an oath to the gods to uphold the terms of a treaty exercised considerable normative force. When, however, this restraining influence was overpowered by the irresistible dictates of realpolitik, as Thucydides describes during the Peloponnesian War (History of the Peloponnesian War 1.78.4, 85.2, 5.15.4), there was no human agency to enforce compliance (see, for example, Thucydides, History of the Peloponnesian War 5.18.9; Low 2007; Sheets 1994). The same was true of the religiously underpinned 'rules' that governed the conduct of the Greeks during periods of armed conflict. Admittedly, the Greeks generally respected heralds, holy days, rights of asylum, the sanctity of temples and the dignity of the dead (Goodman and Holladay 1986; Ober 1996; cf. Krentz 2002). Such conventions, however, could and were broken (cf. Thucydides, History of the Peloponnesian War 4.97.2-3; Xenophon, Hellenica 3.5.23-4), and although the Greeks sometimes fought for restricted tactical goals, such as control of borderland (cf. Herodotus, The Histories 1.82.1-8, Pausanias, Description of Greece 2.38.5), it would be a grave mistake to imagine that their wars were, in any meaningful sense, limited.

Between the $10^{\text {th }}$ and the $7^{\text {th }}$ centuries $\mathrm{BC}$, for instance, Sparta conquered both Laconia and Messenia and turned their hitherto free populations into helots: servile agricultural labourers whose exploitation allowed the Spartans to devote themselves to the art of war (Aristotle, The Politics 2.1271b; Tyrtaeus fr.6; Cartledge 2002b). Political dissolution and helotisation however, was not the worst fate a defeated Greek polis could suffer. As the historical record reveals, other poleis were conquered and then annihilated by andrapodisation (for examples, see Thucydides, History of the Peloponnesian War, 5.32.1, 116.4), a process which turned people into andrapoda, items of human-footed livestock. As Gaca (2010) demonstrates, this process was preceded by a savage if partial massacre of the 
defeated population which lasted until the survivors entered a state of terrified submission. At this point, any remaining fighting age men were separated and killed (see esp. Rosivach 1999), after which those left, now stripped of all protection, were andrapodised. This entailed the sortation of survivors into two broad categories according to their financial value. In the first category were women, particularly young women, who were probably raped at the point capture, as well as adolescents of both sexes, and older children who no longer required maternal care. They could work, they could be subjected to various types of sexual exploitation, and they presented little security risk. As such, they made ideal slaves, and so were marched to the slave markets or turned over to the slave traders who often followed Greek armies. In the second category were those who did not make ideal slaves, namely the old and the young, whose age-related incapacities reduced their financial value to such an extent that they were usually abandoned to die of exposure.

In the extreme environment of classical Greece, therefore, patriotism was a prerequisite for survival: Greek poleis had to attract the loyalty of their citizens, because if those citizens did not fight on behalf of their collective, that collective could easily fall under the power of another, or worse still, cease to exist. Those poleis, however, evolved into different forms, and the generation of patriotism amongst their respective populations differed accordingly.

\subsection{Democratic Athens}

Athens, for instance, had, by the classical period, escaped the confines of aristocracy and evolved into a radical democracy (Aristotle, Athenian Constitution 25.1-26.1) whose body-politic derived high levels of cohesion from the homogeneity its citizens and the intensity of their interaction (Crowley 2012). As Aristotle reveals, from the mid-fifth century BC, Athenian citizenship was reserved for those whose fathers were Athenian citizens and whose mothers were the daughters of Athenian citizens (Athenian Constitution 42.1-2). 
Admittedly, on rare occasions, citizenship could be granted to outsiders (see, for instance, Thucydides, History of the Peloponnesian War 3.55.3), but beyond such exceptions, it is clear that Athenian citizens formed a biologically delimited group whose monopolisation of power allowed them to enjoy privileges denied to the other inhabitants of Attica.

Of course, within this politically empowered and privileged group, material inequality persisted (Ober 1989), but while the antagonism this produced threatened the solidarity of the body-politic, other aspects of Athenian society served to contain class conflict and consolidate civic cohesion. Slavery, for instance, enhanced cohesion by effectively protecting the poor from the predatory attentions of the rich. As Aristotle reveals (Athenian Constitution 2.1-13.1), it was illegal for one Athenian citizen to enslave another, and so the most exploited section of the Athenian population was not the poor, but those who all Athenians, rich and poor alike, could define themselves against: the slaves, who were, by law, all non-Athenian foreigners (Crowley 2012; Hunt 1998; Ober 1989). Other aspects of Athenian society enabled similar acts of dyadic self-definition: the Athenians believed they were autochthonous, and they defined themselves against all non-Athenians who were necessarily born elsewhere; the Athenians monopolised political power, and they defined themselves against all nonAthenians who were politically excluded; the Athenians could own land in Attica, and they defined themselves against all non-Athenians who were denied that right, and by extension, the privilege of agricultural independence (Cartledge 2002a; Crowley 2012). Thus, whist some Athenians were rich and most were poor, the threat this situation presented was reduced by a wider overarching Athenian identity in which all Athenians, irrespective of their degree of wealth, were politically empowered, free, autochthonous and potential if not always actual land owners.

Self-interest and pragmatism also encouraged Athenians to value and maintain their internal harmony, because conflict would imperil the political monopoly they enjoyed as well 
as the privileges that monopoly entailed (Ober 1989). Although they, unsurprisingly, chose not to eliminate material inequality, they did ameliorate the antagonism it provoked through mechanisms designed for the sharing of political power and the limited redistribution of wealth.

The Athenian elite, accordingly, were permitted to retain their wealth as well as the socio-political influence that wealth bought. This, of course, reflected the nature of Athenian democracy, which avoided Michel's iron law of oligarchy through mass participation, whilst simultaneously relying on decision making processes that entailed oratory at its most daunting. As surviving evidence demonstrates, anyone who wished to propose a decree in the Athenian assembly had to address an often rowdy crowd of thousands of their fellow citizens. Speakers, therefore, had to be confident, articulate and informed, and the time and training this required ensured that whilst technically any Athenian could address the assembly, speakers tended to be members of the elite (Ober 1989).

Wealth, education and political prominence also provided the elite with a direct route to positions of military power. Normally, official positions at Athens were allocated by lot, since the Athenians felt, quite rightly, that that election was quintessentially anti-democratic (Aristotle, Politics 2.1273b-74a, 4.1294b; cf. Athenian Constitution 22.2, 61.1-3). Despite this, they also recognised that candidates for senior military positions required experience and expertise, and in order to select the right men, they compromised their democratic ideals and allowed their commanders to be elected (Aristotle, Athenian Constitution 22.2, 61.1, 64.4). As a result, command positions fell the those with both the skills and the socio-political prominence to attract votes, and so both political and military leadership were largely monopolised by members of the elite (Hamel 1998; Ober 1989).

It would be a mistake, however, to imagine that the masses were passive and powerless, since Athenian democracy placed ultimate power in the hands of ordinary citizens 
(Ober 1989). The elite spoke in the assembly, but the mass decided whose proposals to accept or reject. The elite led on the battlefield, but the mass selected their own leaders and oversaw their authority (Hamel 1998). The elite retained their private wealth, but the mass ensured it was used to fund public activities from which they directly benefited (Liddel 2007). The elite fought and feuded, but the mass regulated their conduct through the democratic courts, which they of course dominated, and by those means forced their socio-political superiors to conform, both actually and ideologically, to their democratic modes of conduct (Ober 1989).

The Athenian mass and elite, then, despite a degree of class-based antagonism, were locked in a symbiotic relationship, and the cohesion this encouraged was further reinforced by the participatory nature of Athenian democracy (Crowley 2012; Ober 1989). This, in the absence of effective means of indirect communication, required Athenians to spend a considerable amount of time together working towards collective goals. In the administration of their polis, for instance, they served in the council that set the agenda for the assembly, they attended the assembly, where they determined state policy, and they sat in the lawcourts, where they dispensed democratic justice. In the observance of their divine duties, they worshipped the same gods, they enjoyed the same religious festivals, and every year, they processed together to the acropolis in honour their divine patron, Athena. Finally, in wartime, they marched together in the same armies, sailed in the same warships, and so fought, killed and died together to advance or defend the same collective cause.

Naturally, such activities offered far more than an opportunity for Athenians to gain collective experiences: the socio-political contexts created by these activities all served as conduits for secondary socialisation, that is to say they formed social environments in which the norms and values of Athenian society could be transmitted and enforced (Crowley 2012). Furthermore, since these contexts formed part of a wider democratic system, the norms and values they transmitted and enforced were all ideologically aligned, and this provided Athens 
with a capacity for socialisation which exceeded even that of the modern nation-state. It is unsurprising, therefore, that, as Todd (1990) notes, that the core norms and values of Athenian society were 'a matter of consensus rather than of conflict.'

Central to this consensus was civic obligation (Liddel 2007), a principle which reflected the Athenian's recognition that the rights and privileges they enjoyed were not free, but rather earned through service to their collective (Thucydides, History of the Peloponnesian War 2.63.1; cf. 8.652.3, also Demosthenes Against Polycles 50.63). This obligation could be discharged in a number of ways, but the most important and prestigious public service was undoubtedly performed on the battlefield (Crowley 2012; Liddel 2007; Roisman 2005). This, naturally, was not something the Athenians took lightly (cf. Aristophanes, Knights 1055-56, Peace 239-41, 1179-81): the military participation ratio in classical Greece was extremely high (Berent 2000; cf. Andreski 1968), and most men had personal experience of the brutal nature of Greek warfare.

This, as Thucydides description of the battle of Delium in 424 demonstrates (History of the Peloponnesian War 4.89.1-101.4), offered supporting roles only for cavalry and light infantry, and focused instead on hoplites. They decided battles by engaging their enemies in close combat, a role which required, as a bare minimum, two essential pieces of equipment: a heavy thrusting spear and a large round shield with a distinctive double grip. Depending on personal wealth, this bare minimum could be augmented with a short sword, carried as a secondary weapon, as well as additional protective equipment such as a helmet, body-armour and greaves (Hanson 1991). This obviously maximised frontal protection at the expense of mobility, and so to protect their vulnerable flanks and rear, hoplites fought in a dense formation, usually eight men deep, called a phalanx (cf. Thucydides, History of the Peloponnesian War 6.67.1). In main force encounters, these formations literally crashed against each other in furious close-quarters combat (cf. Xenophon, Hellenica 4.3.19), but, as 
Krentz (1985) reveals, most casualties were sustained not during battle, but when one side was broken by the other, and slow and clumsy hoplites were cut down by cavalry and light infantry as they fled (Xenophon, Hiero 2.15-16).

The prospect of such an experience was, according to Pindar (fr. 120.5), 'a thing of fear'. A man, however, to qualify as such, had to be able to overcome this fear, to face, in the words of Sophocles (Antigone 640-81), 'the storm of spears' and 'stand his ground where posted' as 'a loyal and brave comrade in the battle line'. Those who passed this test of manhood then enhanced not just their social capital, but also their political status, since military service validated the right to political participation and formed a prerequisite for democratic office holding (Crowley 2012; Liddel 2007).

It is unsurprising, therefore, given the geo-political context of Athens, the nature of her social system and the stridency of her civic ideology, that Athenian citizens exhibited a fervent and highly militarised form of patriotism. In their view, they, their polis, their democratic political system and their way of life were superior to all rivals, a belief expressed most famously during a spectacular event that they believed was quintessentially Athenian: the funeral for the war-dead (Demosthenes, Against Leptines 20.141; cf. Loraux 2006). This, as Thucydides describes (History of the Peloponnesian War 2.34.1-8), was a multi-stage event that started when the bones of the dead were laid in state. After three days, they were then transferred onto carts behind which followed a huge funeral procession heading for Athens' public cemetery, where the remains of the dead were interred in a mass grave to sounds of lamenting women.

At the grave, a prominent Athenian delivered a eulogy to all those present, and several such speeches have survived. The most famous was delivered at the end of the first year of the Peloponnesian War by Pericles, and the words Thucydides (History of the Peloponnesian War 2.35-46) attributes to him reveal a great deal about the nature of Athenian patriotism. 
Pericles started his speech, according to Thucydides, by reminding the Athenians of their past victories, their rise to empire, as well as the creation of their democratic constitution and the unique Athenian way of life that constitution underpinned. He then went on to link this way of life to the character of Athenian men, whose courage and self-sacrifice in the service of their fatherland was so glorious it redeemed all prior transgressions and constituted unimpeachable proof of their social worth. Finally, Pericles finished his speech by exhorting the audience to produce more sons to fill the ranks, and for those of military age to emulate the glorious example set by the dead.

Throughout the speech, Athens stands as an object of adulation, and her power is something Athenian citizens are explicitly invited to gaze upon and fall in love with. In the Periclean oration, then, Athenian patriotism is not merely militant, it is erotic, and so, for an individual to die for Athens was not the tragic end of a human life but its most glorious fulfilment (see, for instance, Demosthenes, Funeral Oration 60.37; Euripides, Trojan Women 400-5; Tyrtaeus 12.21-6; Xenophon, Hellenica 2.4.17, 4.4.6, with Balot 2014; Crowley 2012). Of course, Thucydides, is an idiosyncratic writer, but such sentiments are corroborated by other funeral orations, as well as surviving epigraphic and archaeological evidence (for which see Bradeen 1969; Jacoby 1944; Low 2003; Stupperich 1994). This evidence, furthermore, reveals that in addition to their spectacular public funeral, the Athenian wardead were immortalised on stone war-memorials and, perhaps most tellingly, they were received the kind of religious veneration usually reserved for semi-divine heroes, whose extraordinary actions allowed them to transcend their own mortality (Lysias, Funeral Oration 2.80, with Jacoby 1944).

Religion and patriotism also combine symbiotically in the great Athenian festivals (Connor 1996; Goldhill 1990). The City Dionysia, for instance, offered not just dramatic competitions held in honour of Dionysus, but also a display of imperial tribute collected from 
those states subject to Athenian control, as well as a parade of war-orphans (Aeschines, Against Ctesiphon 3.154; Isocrates On the Peace 8.82). These young men, the sons of the war-dead, who had been supported by the state until the age of eighteen, were presented with a hoplite's panoply (Plato, Menexenus 249a-b; Thucydides, History of the Peloponnesian War 2.46.1), at which point they metaphorically took the places of their dead fathers in the ranks of Athenian warriors.

Similar processes are apparent in the Panathenaea, held in honour of Athens' patron goddess, Athena (for which see Connor 1987; Maurizio 1998; Neils 1994). This featured a huge procession in which cavalry and hoplites processed under arms, and the fruits of the empire they and the Athenian navy established were symbolised by the compulsory participation of imperial subjects as well as the destination of the procession: the acropolis (Lewis 1992; Neils 2005). This prominent locale hosted a number potent patriotic symbols, but the most striking, of course, was the Parthenon. This magnificent temple, built to celebrate victory in the Persian wars, reflected Athenian power not just because it was funded from and stored imperial tribute, but because it housed the most strident portrayal of that power, namely a gigantic statue of Athena, resplendent in the panoply of a hoplite, holding Nikē in her outstretched hand. The meaning conveyed by this idealised Athenian self-image is obvious: as Lewis (1992) famously observed, 'to say that the Athenians built the Parthenon to worship themselves would be an exaggeration, but not a great one'.

\subsection{Oligarchic Sparta}

The Athenians, then, were paradigmatically patriotic, but, in classical Greece, democracies enjoyed no monopoly on patriotism, as Sparta clearly demonstrates. Her citizens, of course, manifested a similar level of militant patriotism, but, unsurprisingly, given the unique nature of Spartan society, this was generated very differently (Balot 2010). Sparta was, in many respects, the polar opposite of Athens, most obviously because her governance 
was not democratic, but oligarchic (for which see esp. Cartledge 2002b). This was made up of four distinct elements, the most striking of which her two kings (see esp. Herodotus, The Histories 6.56.1-59.1, also Xenophon, Spartan Constitution 13.1-11). These men, one from the Agiad royal family, the other from the Euypontid, enjoyed both political influence and religious primacy, as well as the right to lead Spartan armies in the field. However, when compared to the Great King of Persia, their powers were limited, even whilst on campaign. As Thucydides reveals, a Spartan king could be criticised by his troops during the conduct of military operations (History of the Peloponnesian War 5.59.1-60.6, 65.1-4), and for actual or perceived command incompetence, he could be severely punished when he returned home (5.63.1-4). Despite their title, their power and their prestige, therefore, it is perhaps best to view the Spartans kings as hereditary generals.

Certainly, their power was counter-balanced by the other elements of Spartan governance, such as the gerousia (for which see Hodkinson 2012), a council which actually included the kings as well as twenty-eight other men over the age of sixty. Membership was for life and gained through a process of 'competitive acclamation', that is to say, of those put forward, the winning candidate was the individual who received the loudest cheers from the Spartan body-politic. The powers of the gerousia were extensive: it heard certain criminal cases, exercised oversight over laws and customs, and most importantly, it decided what motions could be put before the Spartan assembly. This seems to have been convened once per month, and to have provided Spartan citizens with the opportunity to vote on matters of state and appoint officials such as the ephors (for which see Aristotle, The Politics 2.1270b; Plutarch, The Life of Lysander 28; Xenophon, Spartan Constitution 8.1-5, 15.1-9). Five of these 'overseers' were elected annually from among the Spartan body-politic, and while they could not be reappointed, the powers they exercised during their term of office were considerable: they oversaw the day to day running of Sparta, the conduct of her two kings, 
the operation of her system of state education, as well as the ongoing exploitation of the helots.

This was, of course, a crucial role, because it was the labour provided by the helots that allowed the Spartans to live as a parasitical military elite, but, as contemporaries recognised, this this privilege entailed a high price. As Plato suggests (Laws 6.776d-778a), the safest way to exploit slaves was to take them from different places, so that cultural and linguistic barriers reduce their capacity for collective action. The Spartans however, did the opposite. Their servile populations were enslaved in situ, and whilst the Laconian helots were relatively quiescent, the Messenians resented their exploitation, the brutal regime that enforced it, and they demonstrated an explosive capacity for collective action (see esp. Aristotle, The Politics 1269b; Plutarch, The Life of Lycurgus 28.16; Thucydides, History of the Peloponnesian War 4.80.1-5; Xenophon, Hellenica 3.3.1-11). Naturally, given Spartan reliance on helot labour, a full scale revolt, like that of $464 \mathrm{BC}$ (for which see Thucydides, History of the Peloponnesian War 1.101.1-103.3), presented the Spartans with an existential threat which, unsurprisingly, exercised a determining influence over the nature of their society.

Between the $7^{\text {th }}$ and 5 centuries BC, Spartan society was restructured to maximise the collective unity of the body-politic (for which see Cartledge 2002b). State intervention in the lives of Spartan citizens began shortly after birth, when it was the gerousia, rather than the father, who decided whether or not a male child was fit to be raised (Plutarch, Life of Lycurgus 16.1-3). Boys fortunate enough to pass this initial test were then, at the age of seven, inducted into the agōge, Sparta's system of state education, which, despite its notoriety, remains enigmatic. Scholars (see esp. Cartledge 2001; Ducat 2006a; Kennell 1995) have debated whether its aims were civic, military, or initiatory, and have questioned whether, as commonly supposed, it actually entailed residence away from home, and most 
importantly, whether it co-existed with the kind of private education found in other Greek poleis.

Xenophon, however, provides just enough reliable information (Spartan Constitution 2.1-4.7, with Kennell 1995) for a partial reconstruction. All male Spartans, except the immediate Agiad and Eurypontid heirs, proceeded through three age-stages (broadly corresponding to childhood, adolescence, and adulthood), and until they graduated at the age of thirty, they were subjected to a programme of conditioning designed to inculcate austerity, toughness, obedience, and conformity, as well as the transference of loyalty from the family to the state. Annoyingly, despite his own military experience, Xenophon does not reveal whether the agoge included a sustained degree of tactical training, although this is strongly implied by his criticism of the Athenians for not providing their youth with such instruction (Xenophon, Memorabilia 3.5.15, 12.5), as well as his own discussion of the tactical ability of Spartan troops.

They, as Xenophon reveals (Spartan Constitution 11.5-10), could both manoeuvre on the battlefield and could continue to fight, unlike the rest of the Greeks, when all tactical order was lost. This impressed Xenophon, and indeed the rest of the Greeks (Lysias, For Mantitheus 16.15; Thucydides, History of the Peloponnesian War 4.34.1), but the manoeuvres he describes are rudimentary, and as Aristotle observes (The Politics 1338b), the only thing special about the Spartans' tactical training was that, in world of military amateurism, they actually had some. This, of course, suggests that the focus of the agogge was not purely military, rather, as Hodkinson (2006) and Ducat (2006a) argue, it was an institution designed, in addition to the inculcation of military virtues, to initiate boys into Spartan society and mould them into ideal Spartan citizens.

These aims, indeed, are observable into the other institutions which dominated the lives of adult Spartans. For instance, to qualify as a citizen at Sparta, a man had to a member 
of one of the many common messes, each of which contained about fifteen men. Tellingly, these men had to vote unanimously to accept a new member, and, as Aristotle explains (Politics 1271a) continued membership was contingent upon the payment of monthly dues (in the form of agricultural produce). Impecunious Spartans, therefore, who could not afford such a commitment, faced not just loss of mess membership, but also, by extension, loss of citizenship. For those with the means both to obtain and retain their membership, life within the such an institution was, according to Xenophon (Spartan Constitution 5.1-9), characterised by enforced conformity: men shared the same food, sometimes augmented by donations from wealthier members and from hunting, and the amount a man could eat was strictly regulated; similarly, although alcohol was provided, to avoid socially transgressive conduct, drinking to excess was prohibited; finally, the internalisation of desirable norms and values was enforced by strict rules of etiquette governing behaviour, deportment and conversation.

Conformity was further reinforced by the occupational homogenisation of adult Spartans (for which see Xenophon, Spartan Constitution 7.1-6), who, as fulltime hoplites debarred from economic activity, were functionally indistinct. Material inequality persisted (see esp. Aristotle, The Politics 2.1271a-b; Thucydides, History of the Peloponnesian War, 1.6.1-6, 5.63.1-4), but was suppressed, as was conspicuous consumption, in order to make all Spartans at least superficially similar, which explains why they referred to themselves as the homoioi: the peers.

Finally, according to Xenophon (Spartan Constitution 1.3-10), even marriage and family life were structured to support the state in Sparta. Pressures were focused on men to marry earlier than their counterparts elsewhere in Greece, and the state prepared the women they married for childbearing by putting them through a physical educational system similar to that set out for boys. Overtly eugenic principles also governed sexual relations between 
husband and wife: they were to remain separated after marriage, so that their longing resulted in vigorous sex, and therefore vigorous babies, and a husband could, under certain circumstances, even make his wife sexually available to other male Spartans who wanted to father children. The structure of Spartan society, then, served to homogenise and unify the Spartan body politic, enforce obedience, conformity, and communalisation, and thereby to ensure that the individual's loyalty was primarily attached not to his family, but to the state (see esp. Cartledge 2001; Ducat 2006a; Hodkinson 2006; Kennel 1995). The process of socialisation, then, was very different in Athens and Sparta, but, despite the persuasive protestations of Balot (2010), the end result was largely the same. A man's primary loyalty was to his polis, and in return for membership of that strictly delimited political community, he was reciprocally obligated to serve his collective, if necessary, by fighting, killing and dying on the battlefield.

The normative force of this expectation, despite the very real costs faced by the individual citizens concerned, is revealed in two very obvious ways. The first, of course, is that the vast majority of citizens of Athens and Spartan demonstrated an unhesitating willingness to fight for their collective causes (for Spartan and Athenian military prowess, see Crowley 2012; Lazenby 1985). The second is the fate of those Athenians and Spartans who transgressed this expectation by failing to fight, or fight properly. Their punishment different in detail but rested on the same foundation, namely the sustained application of social pressure. In both poleis, transgressors suffered the loss of their social status, and whilst the social exclusion and the mockery suffered by transgressive Athenians (for which see Crowley 2012) was made even worse at Sparta by a range of customs designed to make the individual's degraded status more visible (for which see Xenophon, Spartan Constitution 9.16; Ducat 2006b, also Herodotus, The Histories 1.82.1-8, 7.231.1-232.1,9.71.1-4; Pausanias, 
Description of Greece 2.38.5; Thucydides, History of the Peloponnesian War 5.41.2), the experience of social death must have seemed very similar indeed.

\section{Co-operation}

The Greeks then, experienced two distinct types of patriotism: 'higher patriotism' which focused on Greek cultural identity, and 'lower patriotism', which fixated on the polis, and this duality provided scope for common action, especially where religion, the one thing Greeks could actually agree on, was concerned. For instance, the Greeks asserted and celebrated their cultural identity by gathering to watch and compete in the circuit of great athletic competitions held at Nemea in honour of Zeus, Olympia, also in honour of Zeus, at Corinth in honour of Poseidon, and at Delphi, in honour of Apollo (Swaddling 2015).

Delphi also hosted another notable example of panhellenic cooperation, namely the Delphic amphictyony. Representatives of this league, which included much of Greece, met in council to administer not just the Pythian Games, but also the sanctuary of Apollo at Delphi and its famous oracle (for which see Parke and Wormell 1956). Here, Greeks received authoritative guidance on a range matters: Xenophon, for instance, consulted the oracle before embarking on mercenary service with the Ten Thousand (Anabasis 3.1.4-7), and during the Persian Wars, the Athenians famously asked the oracle to advise them on strategy (Herodotus, The Histories 7.139.6.1-144.3, 8.77.1-2). The oracles' obvious interstate influence, naturally, was reflected in the role of the amphictyonic council, which was empowered to punish those who offended Apollo, and even to declare a Sacred War (of which four are known) against those found guilty of such an offence (Parke and Wormell 1956).

Ethnicity also provided the basis for interstate co-operation. The Boeotians in central Greece, for example, felt enough of a collective identity to form the Boeotian League. This emerged during the last quarter of the $6^{\text {th }}$ century, and although it suffered setbacks, 
especially during the Persian Wars and the First Peloponnesian War, by $427 \mathrm{BC}$, it had developed an advanced system of federal governance (Buck 1994). This was made up of eleven electoral blocks, to which constituent poleis were assigned according to their size: Thebes, for instance, as the largest Boeotian polis, controlled two of these blocks, whilst smaller states were lumped together as single units. Each block provided one senior executive official as well as sixty councillors for the league council. Similar principles are also reflected in the league's army, which recruited one thousand hoplites from each block as well as one hundred cavalry. This, as both Thucydides (History of the Peloponnesian War 4.89.1-101.1) and Xenophon (Hellenica 6.4.8-15) demonstrate, was an extremely effective fighting force which decisively defeated a large Athenian army at Delium in $424 \mathrm{BC}$, and even more impressively, forever shattered Spartan power at Leuctra in $371 \mathrm{BC}$.

In spite of the impressive achievements of Boeotian federalism, the most famous example of interstate cooperation occurred during the Persian Wars (for which see Lazenby 1993), the final phase of which reveals both the force and the limits of panhellenism. As is well known, to maximise their chances of victory against overwhelming odds, some of the Greeks attempted, by forming the Hellenic League, to pool their resources and meet the invader with a united force. Nevertheless, initial defensive operations ended in failure at Thermopylae in 480 BC (The Histories 7.201.1-234.1), yet, despite this, the League finally succeeded, later that same year, in defeating the Persian fleet at Salamis (8.83.1-98.1) and, in 479 BC, their army at Plataea (9.20.1-72.2). These stunning successes, and their subsequent celebration, then served to sharpen Greek self-definition against the barbarian and thereafter to facilitate the re-imagination of the Persian Wars as a conflict between two diametrically opposed groups, Greeks and Persians, when they were nothing of the sort (for this argument in full, see Hall 1989). 


\section{Conflict}

Greek unity, of course, was nothing more than an illusion. The Serpent Column, the victory monument erected by the Greeks to celebrate their victory in the Persian Wars, is inscribed with the names of only thirty-one Greek poleis, quite simply, because resistance to Persia was only one of the options available (Lazenby 1993; cf. Hansen and Nielsen 2004). Some poleis, such as Argos, remained neutral (Herodotus, The Histories 7.148.1-153.3), whilst others, most famously Thebes, reacted pragmatically to the evolution of events and joined with and fought for the Persians (7.132.1, 157.1-63.2, 205.2-206.1, 233.1-2, 9.2, 40.1). This reveals, of course, that Greeks were guided not by the safety of Greece, but by the interests of their own polis, a conclusion reinforced still further by the self-serving actions of the Hellenic League's two leading states: Athens and Sparta.

Their divergence of interests were largely dictated by geography. Athens, after the fall of Thermopylae in $480 \mathrm{BC}$, was directly exposed to the Persian invasion force and naturally, favoured the commitment of Greek land and naval forces north of the Isthmus of Corinth. Sparta, on the other hand, preferred to keep Greek forces defending the Isthmus in order to prevent invasion of the Peloponnese. Both, of course, sought to influence League policy in accordance with their divergent interests (see esp. Herodotus, The Histories 8.60.1-62.1;cf. Lazeby 1993): the Spartans, focused on the safety of Sparta above all else, were willing to abandon the whole of Greece north of the isthmus and allow Athens to be devastated, while the Athenians threatened to leave the League, and thus expose the Peloponnese to amphibious invasion, in order to force their allies to fight at Salamis in $480 \mathrm{BC}$ and Plataea in $479 \mathrm{BC}$.

Polis primacy also tainted other instances of Greek cooperation. The great athletic festivals, like the Olympic Games, celebrated Greek cultural unity, yet, clearly, the Greeks cooperated primarily in order to compete. Victories enhanced not just the personal prestige of the victorious athlete, but also his polis. This obvious degree of inter-poleis competition at 
Olympia is most strikingly reflected, most tellingly, in the practice of erecting monuments advertising military victories at the site (such as the Nikē of Paeonius, which, according to Pausanias' Description of Greece 5.26.1, celebrates the Messenian part in the defeat of the Spartans on Sphacteria in 425 BC, described in Thucydides' History of the Peloponnesian War 4.3.1-6.2, 8.1-23.2, 26.1-40.2), where they could be seen by Greeks from across the Hellenic world.

Similar processes are also observable in the working of the Delphic Amphictyony, which was used, on a number of occasions, by member states as little more than a convenient mechanism to further their own regional interests and hegemonic aspirations (see, for instance, Hornblower 2009; Low 2007). Not even Boeotian federalism was free of polis primacy. For much of its history, the confederacy was dominated by Thebes which increased its power relative to other member states and used that power to direct federal policy in the direction of Theban interests (Thucydides, History of the Peloponnesian War 4.91.1; Buck 1994; Low 2007).

\section{The Limits of Hegemony}

The Greeks then, were able to look beyond the confines of the polis, but nevertheless, the polis always came first, and this undermined even hegemonic ambitions of the two traditional Greek superpowers. Sparta, for instance, led a coalition of Peloponnesian poleis which modern historians refer to as the Peloponnesian League (for which see Thucydides, History of the Peloponnesian War 1.19.1, 67.1-86.5, 144.2, with Cartledge 1987). Members swore to have the same friends and enemies as Sparta and to follow her as hegemon, and Sparta swore to come to the aid of any member state attacked by a third party. Together, they decided collective action in the league's assembly, in which each member possessed one vote, and while this deliberative body could not impose a decision on Sparta, since she was 
not bound by its resolutions, she could not unilaterally impose a decision on members, since any proposal required a majority decision to pass.

Despite the progressive nature of the Peloponnesian League, there was, however, no real pooling of sovereignty. Admittedly, members were united under Spartan hegemony, and on occasion pursued commons goals (cf. Thucydides, History of the Peloponnesian War 1.67.1-88.1), yet, the league existed to serve Spartan interests, in that its primary purpose was to guarantee her exploitation of the helots: members agreed not to harbour runaways, and to aid Sparta in the event of a revolt (Plutarch, Moralia 292b; Thucydides, History of the Peloponnesian War 4.80.3, 5.23.3; cf. Cartledge 1987). As long as they did that, member states, which were allied only to Sparta and not each other, were free to pursue their own interests to such an extent that they were actually able, under the terms of their membership, to wage wars against each other (Thucydides, History of the Peloponnesian War 1.103.4, 4.134.1-2, 5.29.1, 33.1-3; Xenophon, Hellenica 5.4.37).

Similar limitations are observable in hegemony established by Athens. This started with the Delian League (so-called by modern historians because its assembly originally met on the island of Delos), which was set up after the Persian Wars when a coalition of the willing came together under Athenian leadership to seek mutual protection, as well as vengeance and plunder, from the Persian Empire. This venture initially proved popular, and many poleis enrolled and contributed financially or militarily to the panhellenic cause. This, however, was gradually eclipsed by Athenian interests, as Athens slowly converted the Delian League into an Aegean empire (Thucydides, History of the Peloponnesian War 1.89.1-117.3, with Low 2007).

This increasing imperialism, as Thucydides reveals, prompted revolts from erstwhile allies, who resented the imposition of Athenian 'tyranny' as well as their own 'enslavement'. Their resistance, however, was met by coercive forms of imperial control, including forcible 
regime change, the installation of supervisory officials, the imposition of garrisons, the settlement of Athenian citizens in confiscated portions of 'allied' land, and even measures designed to limit free speech (see above, with Low 2005, also Rhodes 1994). Worse still, Athens responded to revolts with the merciless application of military force (ironically paid for by the member states' own contributions), which, on a number of occasions, culminated in the punitive slaughter of the rebel state's citizens and the andrapodisation of their dependents.

The one thing the Athenians did not do, however, was pool sovereignty with their allies. They, like the rest of the Greeks, jealously guarded their citizenship, and so their imperial subjects remained perpetually excluded and exploited outsiders. As such, there was nothing keeping them together beyond the coercive power of their hegemon (Thucydides, The History of the Peloponnesian War 5.89.1; Runciman 1990), which, of course, was a fragile basis for the lasting aggregation of power, especially in the geo-political environment of classical Greece. This, as the historical record demonstrates, tended to act as self-balancing system, in which the rise of one major power was balanced by the combined resistance of the others, who feared the infringement of their own autonomy. Put simply, the Athenian hegemony was opposed by Sparta and Thebes; the Spartan hegemony that followed it was opposed by Athens and Thebes; the Theban hegemony was opposed by Athens and Sparta, and all three ultimately failed (for this argument specifically, see Hunt 2010; Strauss 1991, and for an excellent overview of this period, see Hornblower 2002, also Rhodes 2005).

\section{Conclusion}

The Greeks then, shared a panhellenic identity, but, even when this was bolstered by a common religious or ethnic identity, or indeed fear of an outside power, their panhellenism was ultimately subordinated to and overpowered by the incredible degree of patriotism they felt for their individual poleis. This, in many respects, reflected the unstable and fragmented 
environment of ancient Greece, but, whilst polis patriotism acted as a much needed forcemultiplier on the battlefield, it also prevented the pooling of sovereignty necessary to support lasting the lasting aggregation of extra-polis power. Consequently, when faced by the rise of Macedon, the Greeks, still atomised in their micro-states and locked in endless internecine conflict, lacked the unity required for successful resistance, and so the period after $338 \mathrm{BC}$ belongs not to the parochially patriotic Greeks, but to Phillip, Alexander, and the Macedonians.

Dr. Jason Crowley

Senior Lecturer in Ancient Greek History The Manchester Metropolitan University 


\section{References}

Andreski, S. (1968). Military organization and society, 2nd edn. London. Routledge and Keegan Paul.

Balot, R. (2010). Democratizing Courage in Classical Athens. In D. Pritchard (ed.), War, democracy and culture in classical Athens (pp.88-108). Cambridge. Cambridge University Press.

(2014). Courage in the democratic polis: Ideology and critique in classical Athens. Oxford. Oxford University Press.

Berent, M. (2000). Anthropology and the classics: War, violence, and the stateless polis', Classical Quarterly 50: 257-89.

Bradeen, D. W. (1969). The Athenian casualty lists. Classical quarterly 19: pp.145-59.

Buck, R. J. (1994). Boiotia and the Boiotian league 432-371 BC. Edmonton. University of Alberta Press.

Burkert, W. (1985). Greek religion: Archaic and classical. Oxford. Basil Blackwell.

Cartledge, P. (1987). Agesilaos and the crisis of Sparta. London. Duckworth.

(2001). A Spartan education. In P. Cartledge (ed.), Spartan reflections (pp.79-90). London. Duckworth.

(2002a). The Greeks: A portrait of self and others, $2^{\text {nd }}$ edition. Oxford. Oxford University Press.

(2002b). Sparta and Lakonia: A regional history 1300 to 362 BC. London. Routledge and Keegan Paul.

Connor, W. R. (1987). Tribes, festivals and processions: Civic ceremonial and political manipulation in archaic Greece. Journal of Hellenic studies 107: pp.40-50.

(1996). Civil society, Dionysiac festival and the Athenian democracy. In J. Ober and C. Hedrick (ed.), Demokratia: A conversation on democracies ancient and modern (pp.217-26). Princeton. Princeton University Press.

Crowley, J. (2012). The psychology of the Athenian hoplite: The culture of combat in classical Athens. Cambridge. Cambridge University Press.

Ducat, J. (2006a). Spartan education: Youth and society in the classical period. Swansea. Classical Press of Wales.

(2006b). The Spartan 'tremblers'. In S. Hodkinson and A. Powell (eds.), Sparta and war. Swansea (pp.1-55). Classical Press of Wales.

Evans, M. M. \& Abrahams, E. B. (1964). Ancient Greek dress. Chicago. Argonaut. 
Finley, M. I. (1983). Politics in the ancient world. Cambridge. Cambridge University Press.

Gaca, K. (2010). The andrapodizing of war captives in Greek historical memory. Transactions and Proceedings of the American Philological Association 140: pp.11761.

Goldhill, S. (1990). The Great Dionysia and civic ideology. In J. J. Winkler and F. I. Zeitlin (eds.) Nothing to do with Dionysos?: Athenian drama in its social context (pp.97129). Princeton. Princeton University Press.

Goodman, M. D. and Holladay, A. J. (1986). Religious scruples in ancient warfare. Classical quarterly 36: pp.151-71.

Hall, E. (1989). Inventing the barbarian: Greek self-definition through tragedy. Oxford. Oxford University Press.

Hamel, D. (1998) Athenian generals: Military authority in the classical period. Leiden. Brill.

Hansen, M. H. \& Nielsen, T. H. (2004). An inventory of archaic and classical poleis: an investigation conducted by the Copenhagen polis centre for the Danish national research foundation. Oxford. Oxford University Press.

Hanson, V. D. (1991). Hoplite technology in phalanx battle. In V. D. Hanson (ed.), Hoplites: The classical Greek battle experience (pp.63-84). London. Routledge.

(2009). The western way of war: Infantry battle in classical Greece. Berkeley. University of California Press.

Hodkinson, S. (2006). Was classical Sparta a military society? In S. Hodkinson and A. Powell (eds.), Sparta and war (pp.111-62). Swansea. Classical Press of Wales.

(2012). Gerousia. In E. Eidinow and S. Hornblower (eds.), The Oxford Classical Dictionary, $4^{\text {th }}$ edition. Oxford. Oxford University Press.

Hornblower, S. (2002). The Greek world: $470-323$ BC. London. Routledge.

(2009). Did the Delphic amphictiony play a political role in the classical period? In I. Malkin, C. Constantakopoulou and K. Panagiopoulou (eds.), Greek and Roman networks in the Mediterranean (pp.39-56). London. Routledge.

Hunt, P. (1998). Slaves, warfare, and ideology in the Greek historians. Cambridge. Cambridge University Press.

(2010). War, peace, and alliance in Demosthenes' Athens. Cambridge. Cambridge University Press.

Jacoby, F. (1944). Patrios nomos: State burial in Athens and the public cemetery in the Kerameikos', Journal of Hellenic Studies 64: pp.37-66. 
Kennell, N. M. (1995). The gymnasium of virtue: Education and culture in ancient Sparta. London. University of North Carolina Press.

Krentz, P. (1985). Casualties in hoplite battles. Greek, Roman and Byzantine studies 26: 1320.

(2002). Fighting by the rules: The invention of the hoplite agōn', Hesperia 71: pp. 23-39.

Lazenby, J. F. (1985). The Spartan army. Warminister. Aris and Phillips.

(1993). The defence of Greece, 490-479 BC. Warminister. Aris and Phillips.

Lewis, D. M. (1992). The thirty years peace. In D. M. Lewis, J. Boardman, J. K. Davies and M. Ostwald (eds.), The Cambridge ancient history, Vol. 5: The fifth century $\mathrm{BC}, 2^{\text {nd }}$ edition. Cambridge. Cambridge University Press.

Liddel, P. P. (2007). Civic obligation and individual liberty in ancient Athens. Oxford. Oxford University Press.

Loraux, N. (2006). The invention of Athens: The funeral oration in the classical city, $2^{\text {nd }}$ ed. New York. Zone Books.

Low. P. (2003). Remembering war in fifth-century Greece: Ideologies, societies and commemoration beyond democratic Athens', World archaeology 35: pp.98-111.

(2005) Looking for the language of Athenian imperialism. The journal of Hellenic studies 125: pp.93-111.

(2007). Interstate relations in classical Greece: Morality and power. Cambridge. Cambridge University Press.

Mitchell, L. (2007). Panhellenism and the barbarian. Swansea. Classical Press of Wales.

Maurizio, L. (1998). The Panathenaic procession: Athens' participatory democracy on display? In Boedeker and K. A. Raaflaub (eds.), Democracy, empire and the arts in fifth-century Athens (pp.297-317). London. Harvard University Press.

Murray, O. (2012). Polis. The Oxford classical dictionary, $4^{\text {th }}$ edition. Oxford. Oxford University Press.

Neils, J. (1994) The Panathenaia and Kleisthenic ideology. In W. D. E. Coulson, O. Palagia, T. L. Shear, H. A. Shapiro and F. J. Frost (eds.), The archaeology of Athens and Attica under the democracy (pp.151-60). Oxford. Oxbow.

(2005). The Parthenon: From antiquity to the present. Cambridge. Cambridge University Press.

Ober, J. (1989) Mass and elite in democratic Athens: Rhetoric, ideology, and the power of the people. Princeton. Princeton University Press. 
(1996). The rules of war in classical Greece. In J. Ober (ed.), The Athenian revolution: Essays on ancient Greek democracy and political theory (pp.53-71). Princeton. Princeton University Press.

Parke, H. W. and Wormell, D. E. W. (1956). The Delphic oracle. Oxford. Blackwell.

Price, S. R. F. (1999). Religions of the ancient Greeks. Cambridge. Cambridge University Press.

Rhodes, P. J. (1994). The Athenian empire. Oxford: Oxford University Press.

(2005). History of the classical Greek world: 478 - 323 BC. Oxford. Blackwell Publishing Ltd.

Roisman, J. (2005). The Rhetoric of manhood: Masculinity in the Attic orators. Berkeley. University of California Press.

Rosivach, V. J. (1999). Enslaving "barbaroi" and the Athenian ideology of slavery. Historia zeitschrift für alte geschichte 48: pp.129-57.

Runciman, W. G. (1990). Doomed to extinction: The polis as an evolutionary dead-end. In O. Murray \& S. Price, eds. The Greek city from Homer to Alexander (pp.347-67). Oxford: Oxford University Press.

Sheets, G. A. (1994). Conceptualising international law in Thucydides. American journal of philology 115.1: pp.51-73.

Strauss, B. S. (1991). Of balances, bandwagons, and ancient Greeks. In R. N. Lebow and B.

S. Strauss (eds.), Hegemonic rivalry: From Thucydides to the nuclear age (pp.189-210). Oxford. Westview Press.

Stupperich, R. (1994). The iconography of Athenian state burials in the classical period. In W. D. E. Coulson, O. Palagia, T. L. Shear, H. A. Shapiro and F. J. Frost (eds.), The archaeology of Athens and Attica under the democracy (pp.93-103). Oxford. Oxbow.

Swaddling, J. (2015). The ancient Olympic games, $3^{\text {rd }}$ edition. London. British Museum Press.

Todd, S. C. (1990). 'Lady Chatterley's lover and the Attic orators: The social composition of the Athenian jury', Journal of Hellenic studies 110: pp.146-73.

(1993). The shape of Athenian law. Oxford. Oxford University Press.

Wilkins, J. \& Hill, S. (2006). Food in the ancient world. Oxford. Blackwell Publishing. 